\title{
Article Retraction
}

The Editorial Committee of Contexto Internacional has decided, upon deliberation, to retract the following research article:

Igor Abdallah Medina de Souza, The Uruguay Round and Africa: A Liberal Approach to the Trade Regime, Contexto Internacional, December 2014. http://dx.doi.org/10.1590/S0102-85292014 000200003

Since it is a close transcription (with the exception of some parts) of a previously published paper:

Igor Abdallah Medina de Souza, "An offer developing countries could not refuse: how powerful states created the World Trade Organisation," Journal of International Relations and Development, 9 August 2013. doi:10.1057/jird.2013.18

I would like to emphasise that the retraction process aims to correct and guarantee the integrity of academic communications and does not, in any way, represent a punishment to authors. Retraction is a fundamental mechanism to alert readers of problems related to already published manuscripts.

Best regards,

Carolina Moulin

Chief Editor

Contexto Internacional 